\title{
Pegylated-interferon- $\lambda$ treatment-induced peripheral interferon stimulated genes are associated with SARS-CoV-2 viral load decline despite delayed T cell response in older individuals
}

Authors:

Deanna M Santer*1, Daniel Li*2,3,4, Yanal Ghosheh"3,4, Muhammad Atif Zahoor ${ }^{3,4}$, Dhanvi Prajapati ${ }^{1}$, D Lorne J Tyrrel1 ${ }^{5}$, Jordan J Feld ${ }^{\wedge 2,3,4}$, Adam J Gehring ${ }^{\wedge 2,3,4}$

${ }^{1}$ Department of Immunology, University of Manitoba, Winnipeg, MB, Canada

${ }^{2}$ Institute of Medical Science, University of Toronto, Toronto, ON, Canada

${ }^{3}$ Toronto Centre for Liver Disease, University of Toronto, Toronto, ON, Canada

${ }^{4}$ University Health Network, University of Toronto, Toronto, ON, Canada

5 Department of Medical Microbiology \& immunology, Li Ka Shing Institute of Virology, University of Alberta, Edmonton, AB, Canada

* Contributed equally to the work

${ }^{\wedge}$ Contributed equally to the work 
medRxiv preprint doi: https://doi.org/10.1101/2022.02.24.22271438; this version posted March 3, 2022. The copyright holder for this preprint (which was not certified by peer review) is the author/funder, who has granted medRxiv a license to display the preprint in perpetuity.

It is made available under a CC-BY-NC-ND 4.0 International license.

\begin{abstract}
Interferons (IFNs) are antiviral cytokines induced very early after SARS-CoV-2 infection and are crucial for viral clearance, shaping immunity, and preventing the development of severe COVID19. We previously demonstrated that a single injection of peginterferon-lambda1 (PEG-IFN- $\lambda$ ) accelerated viral clearance in COVID-19 patients. To determine if the rapid viral decline was mediated by enhanced immunity, we assessed in vivo responses to PEG-IFN- $\lambda$ by single cell RNA sequencing and measured SARS-CoV-2-specific T cell and antibody responses between placebo and PEG-IFN- $\lambda$-treated patients. PEG-IFN- $\lambda$ treatment induced interferon stimulated genes in peripheral immune cells expressing IFNLR1, with plasmacytoid dendritic cells having the greatest response, followed by B cells. PEG-IFN- $\lambda$ did not significantly affect SARS-CoV-2-specific antibody levels in plasma or the magnitude or functionality of virus-specific T cells. However, we identified a delayed $\mathrm{T}$ cell response in older adults, suggesting that PEG-IFN- $\lambda$ can overcome the delay in adaptive immunity to accelerate viral clearance in patients most at risk for severe disease. Taken together, PEG-IFN- $\lambda$ offers an early COVID-19 treatment option for outpatients to boost innate antiviral defenses without dampening peripheral SARS-CoV-2 adaptive immunity
\end{abstract}


medRxiv preprint doi: https://doi.org/10.1101/2022.02.24.22271438; this version posted March 3, 2022. The copyright holder for this preprint (which was not certified by peer review) is the author/funder, who has granted medRxiv a license to display the preprint in perpetuity.

It is made available under a CC-BY-NC-ND 4.0 International license .

\section{Introduction}

SARS-CoV-2, the cause of COVID-19, has led to a pandemic that has resulted in more than 5.8 million deaths worldwide (https://coronavirus.jhu.edu/map.html). With the emergence of variants and the possibility of breakthrough infections, it is widely believed that SARS-CoV-2 will become an endemic virus ${ }^{1}$. Consequently, finding safe and effective treatments for COVID-19 remains a priority to prevent hospitalizations and deaths, and to expedite recovery in unvaccinated individuals or breakthrough infections.

Interferons (IFNs) are a crucial part of the innate antiviral immune response and drive the expression of a wide array of genes with antiviral and immunoregulatory properties, collectively known as interferon-stimulated genes (ISGs) ${ }^{2}$. Two families of IFNs contribute directly to the innate antiviral response at mucosal barriers in humans- type I (eg. IFN- $\alpha$, IFN- $\beta$ ) and type III (IFN- $\lambda \mathrm{s})$. The broad pleiotropic effects of ISGs can overcome antiviral resistance, making type I or III IFNs potential therapeutics for new and/or highly diverse viruses. Recent studies have found a link between severe COVID-19 and deficiencies in or autoantibodies to type I IFN, while stronger type I IFN responses have been associated with asymptomatic infection ${ }^{3}$, highlighting the critical role of IFNs in disease evolution ${ }^{4-6}$. Like other viruses, SARS-CoV-2 encodes proteins to antagonize IFN responses ${ }^{7-10}$, however supplementing the natural IFN response with IFN treatment has been found to be effective against the virus ${ }^{7,10-13}$.

Type III IFNs act primarily at mucosal barriers through binding a unique heterodimeric receptor (IFN- $\lambda$ R1/IL-10RB) to promote innate antiviral immunity ${ }^{14-17}$. Restricted IFN- $\lambda$ receptor distribution and a lack of IRF1 induction ${ }^{18}$ result in influenza viral load decline without inflammatory side effects in mice treated with IFN- $\lambda$, whereas mice treated with Type I IFN show 
medRxiv preprint doi: https://doi.org/10.1101/2022.02.24.22271438; this version posted March 3, 2022. The copyright holder for this preprint (which was not certified by peer review) is the author/funder, who has granted medRxiv a license to display the preprint in perpetuity. It is made available under a CC-BY-NC-ND 4.0 International license .

impaired survival ${ }^{19}$. However, the IFN- $\lambda$ receptor is not solely restricted to epithelial barriers. We previously showed that functional type III IFN receptors are expressed on human immune cells, including $\mathrm{B}$ and $\mathrm{T}$ cell populations ${ }^{20}$. IFN- $\lambda 3$ pre-treatment of human CD4+ T cells significantly inhibited human immunodeficiency virus-1 infection ${ }^{20}$. However, IFN- $\lambda 3$ addition to peripheral blood mononuclear cells (PBMCs) also inhibited influenza vaccine-induced antibody production in vitro ${ }^{21,22}$. Recently, our group conducted a phase II placebo-controlled randomized trial of peginterferon-lambda (PEG-IFN- $\lambda$ ), a type III IFN, as therapy for mild-to-moderate COVID-19 in outpatients. PEG-IFN- $\lambda$ treatment accelerated viral clearance compared to placebo without inflammatory side effects ${ }^{11}$. When controlling for baseline viral load, PEG-IFN- $\lambda$-treated patients were more likely than placebo patients to have undetectable viral load by day $7(\mathrm{OR}=4.12, \mathrm{p}=$ 0.029 ) and this effect was particularly pronounced in patients with a baseline viral load above $10^{6}$ copies $/ \mathrm{mL}(\mathrm{OR}=6.25, \mathrm{p}=0.012)$. Whether the accelerated viral decline was related to direct antiviral properties of IFN- $\lambda$ and/or enhancement of the SARS-CoV-2-specific immune response was not defined in the clinical study ${ }^{11}$.

It is currently unknown how PEG-IFN- $\lambda$ treatment affects virus-specific T and B cell responses in patients during an acute viral infection. Given the accelerated viral decline observed with therapy, we hypothesized that PEG-IFN- $\lambda$ treatment induced a more robust SARS-CoV-2specific specific $\mathrm{T}$ cell responses and dampened antibody production compared to placebo. We analyzed longitudinal $\mathrm{T}$ cell and antibody responses after therapy using single-cell RNA sequencing (scRNAseq), measurement of the SARS-CoV-2 specific antibody levels in plasma, and the magnitude and functionality of SARS-CoV-2-specfic T cells. ScRNAseq confirmed in vivo responses to PEG-IFN- $\lambda$ in specific peripheral immune cells, but treatment did not alter virusspecific adaptive immune responses. In fact, the antiviral effects of PEG-IFN- $\lambda$ were observed 
medRxiv preprint doi: https://doi.org/10.1101/2022.02.24.22271438; this version posted March 3, 2022. The copyright holder for this preprint (which was not certified by peer review) is the author/funder, who has granted medRxiv a license to display the preprint in perpetuity.

It is made available under a CC-BY-NC-ND 4.0 International license .

despite a delayed $\mathrm{T}$ cell response in older patients at risk of more severe outcomes. Overall, PEGIFN- $\lambda$ treatment for COVID-19 is a promising early treatment that can accelerate viral clearance in patients with delayed $\mathrm{T}$ cell immunity.

\section{Results}

\section{Patient Characteristics}

Sixty ambulatory patients with mild-to-moderate laboratory-confirmed COVID-19 were recruited within 7 days of symptom onset or the first positive nasopharyngeal swab and randomized to a single subcutaneous injection of $180 \mu \mathrm{g}$ of PEG-IFN- $\lambda$ or saline placebo between May and August 2020, prior to the emergence of prominent SARS-CoV-2 variants-of-concern in Canada $^{11}$. PBMCs were isolated from samples collected at the day of enrollment (pre-injection, D0), 3 days (D3), 7 days (D7), and 90+ days (D90+) after PEG-IFN- $\lambda$ or placebo. The range of sample collection for D90+ was 96 to 195 days from D0.

Of the 60 participants in the trial, $\mathrm{T}$ cell analysis was performed on 38 patients, including $17(44.7 \%)$ in the placebo arm and $21(55.3 \%)$ who received a dose of PEG-IFN- $\lambda$. The median age of those studied was 45 years old and 15 (39.5\%) were women. Antibody analyses included data from 27 patients, 1 of whom did not provide PBMCs for T cell analysis. D0, D3, and D7 samples from nine patients (5 PEG-IFN- $\lambda$ and 4 placebo) were used for scRNAseq analysis (Table 1 and Supplemental Table 1). 
medRxiv preprint doi: https://doi.org/10.1101/2022.02.24.22271438; this version posted March 3, 2022. The copyright holder for this preprint (which was not certified by peer review) is the author/funder, who has granted medRxiv a license to display the preprint in perpetuity.

It is made available under a CC-BY-NC-ND 4.0 International license .

Specific peripheral blood immune cells are responsive to PEG-IFN- $\lambda$ in vivo

Our prior in vitro experiments showed that subsets of peripheral blood immune cells express the IFN- $\lambda$ receptor subunit IFN- $\lambda \mathrm{R} 1$ and respond to IFN- $\lambda$ exposure with up-regulation of ISGs $^{20}$. To determine if a peripheral immune cell response to therapeutic administration of PEGIFN- $\lambda$ in vivo could be detected, we performed scRNAseq on 9 patients from the clinical study. All 5 patients chosen for scRNAseq analysis who received PEG-IFN- $\lambda$ demonstrated accelerated virus clearance compared to placebo-treated patients by day 3-5 post-treatment. scRNAseq was performed to investigate expression of the IFN- $\lambda$ receptor (IFN- $\lambda$ R1/IL-10RB) and ISG responses in individual immune cell populations.

After filtering for high quality cells, we included 263,668 cells in our analysis; 146,408 cells from PEG-IFN- $\lambda$-treated and 117,260 from placebo-treated patients. Clustering yielded 21 unique cellular populations (Fig. 1A). Expression of the heterodimeric IFN- $\lambda$ receptor, IL10RB and IFNLRI, was visualized using feature plots. Expression of IFNLRI was concentrated in specific immune populations, primarily clusters 2, 6, 10, and 16 (Fig. 1B) whereas IL10RB was ubiquitously expressed by immune cells (Fig. 1C). Cell types were identified using canonical marker genes displayed in the dot plots (Fig. 1D). Cluster 2 was granzyme B (GzmB)+ CD8 T cells, clusters 6 and 10 were B cells and cluster 16 was plasmacytoid dendritic cells (pDCs). Each of these populations were previously demonstrated to respond to IFN- $\lambda$ in vitro $^{20,23}$.

We then determined which clusters expressed the highest level of each receptor component and what frequency of the cells had detectable receptor expression. Cluster 16 (pDCs) expressed the highest level of IFNLR1 (Fig. 1D-E) while clusters 3, 8, and 15 (monocytes), expressed the highest level of $I L-10 R B$, but no IFNLR1, consistent with our previous work (Fig. 1D-F) ${ }^{20}$. To 
medRxiv preprint doi: https://doi.org/10.1101/2022.02.24.22271438; this version posted March 3, 2022. The copyright holder for this preprint (which was not certified by peer review) is the author/funder, who has granted medRxiv a license to display the preprint in perpetuity. It is made available under a CC-BY-NC-ND 4.0 International license .

measure the response to PEG-IFN- $\lambda$, we developed a composite module score that factored in gene expression from 24 known ISGs (Supplementary Table 2). ISG module scores declined over time indicating that ISG expression was elevated at baseline in both PEG-IFN- $\lambda$ and placebo patients (Fig 1G-J). However, upon PEG-IFN- $\lambda$ treatment, pDCs maintained an elevated ISG response at D3 post treatment compared to D0 (Fig. 1G), which was not observed in monocytes (no IFNLRI expression) or the placebo-treated patients (Fig. 1H). The frequency of IFNLRI+ cells in the other clusters was too low to observe a change in the ISG module score. Therefore, we enriched for IFNLR1+ cells from B cell clusters 6 and 10 and measured the response to PEG-IFN- $\lambda$ via the ISG module score, which demonstrated positive ISG responses at D3 for B cells in both clusters 6 and 10 when compared to D0 (Fig 1I, J). Overall, these analyses demonstrated that IFNLRI+ immune cells in the peripheral blood responded to PEG-IFN- $\lambda$ treatment in COVID-19 patients.

Pegylated-IFN- $\lambda$ treatment did not affect SARS-CoV-2-specific antibody levels compared to placebo

Antibody response to SARS-CoV-2 is a primary metric of protection following vaccination or prior exposure. To investigate the effect of PEG-IFN- $\lambda$ on B cell responses, we quantified levels of total IgM, IgG and IgA in patient plasma (placebo; $n=11-12$ and PEG-IFN- $\lambda$; $n=14-15$ for each time point) at D0, D7, and D90+. Total IgG levels were significantly higher at D0 and D7 compared to D90+ in both groups, indicating an increase in total IgG during early infection (Fig. 2A). We found there were no differences in total $\operatorname{IgM}, \operatorname{IgG}$, or $\operatorname{IgA}$ levels between placebo- and PEG-IFN- $\lambda$-treated patients at D0, D7, or D90+ post-enrollment (Fig. 2A). Additionally, total IgM decreased between D0 and D90+ in the PEG-IFN- $\lambda$ patients, while both groups showed a decrease 
medRxiv preprint doi: https://doi.org/10.1101/2022.02.24.22271438; this version posted March 3, 2022. The copyright holder for this preprint (which was not certified by peer review) is the author/funder, who has granted medRxiv a license to display the preprint in perpetuity.

It is made available under a CC-BY-NC-ND 4.0 International license .

in total IgM between D7 and D90+ (Fig. 2A). For total IgA, there were significant differences in the placebo group, increasing between D0 and D7, and decreasing between D7 and D90+ (Fig. 2A).

To measure receptor binding domain (RBD)-specific IgG, IgM, and IgA antibody levels we utilized a spike (RBD)-specific ELISA protocol in patient plasma from each treatment group. Eight pre-pandemic plasma samples (from 2018-2019) were used as negative controls and displayed very little background (Fig. 2B, dotted lines). We observed a significant increase in RBD-specific antibodies in plasma from D0 to D7 for all subclasses. We also found no differences in RBD-specific IgG, IgM, or IgA levels at all three time points when comparing placebo- and PEG-IFN- $\lambda$-treated patients (Fig. 2B). At D90+, only RBD-specific IgG was still significantly elevated compared to D0 and D7, whereas both $\operatorname{IgA}$ and $\operatorname{IgM}$ antibody levels significantly decreased between D7 and D90+ (Fig. 2B). The decrease of RBD-specific IgA and IgM levels at D90+ was consistent between placebo and PEG-IFN- $\lambda$ groups. RBD-specific IgG, IgA, and IgM levels correlated between patients at D7 (Supplementary Table 3). At D90+ when RBD-specific IgM and IgA antibodies were lower, there were no significant correlations between RBD-specific IgG, IgA, or IgM levels.

Overall, these results indicate that COVID-19 patients in both groups mounted RBDspecific antibodies above background and PEG-IFN- $\lambda$ treatment did not inhibit B cell antibody responses measured in plasma. 
medRxiv preprint doi: https://doi.org/10.1101/2022.02.24.22271438; this version posted March 3, 2022. The copyright holder for this preprint (which was not certified by peer review) is the author/funder, who has granted medRxiv a license to display the preprint in perpetuity.

It is made available under a CC-BY-NC-ND 4.0 International license .

\section{Pegylated-IFN- $\lambda$ treatment did not affect $\mathrm{T}$ cell responses compared to placebo}

SARS-CoV-2-specific T cell responses towards the wild-type membrane (M), envelope (E), nucleocapsid (N), and spike (S) protein were measured in 38 clinical trial patients (placebo; $\mathrm{n}$ $=17$ and PEG-IFN- $\lambda ; \mathrm{n}=21)$ at three time points. We used an ex vivo three-colour fluorospot assay detecting IFN- $\gamma$, IL-2, and granzyme B (GzmB) on patient PBMCs stimulated with SARSCoV-2 peptides for 24 hours. A response was considered positive when the average spot forming units (SFUs) of duplicate wells exceeded 2 times the individual's DMSO-stimulated negative control SFU count and greater than the mean negative SFU count from all patients. SFU counts were normalized by subtracting the background DMSO-stimulated SFU count of the individual patient time point.

More than $50 \%$ of patients showed positive $\mathrm{T}$ cell responses at D0, which was within 7 days of symptom onset and laboratory-confirmed SARS-CoV-2 infection (Supplementary Fig. 1). Robust IFN- $\gamma$ and IL-2 responses were readily observed, whereas less than half of the patients displayed positive GzmB responses towards $\mathrm{M}, \mathrm{E}, \mathrm{N}$, and $\mathrm{S}$ protein at any of the time points (Supplementary Fig. 2). The number of responses towards E were lower than responses to the other proteins. The median envelope responses across all time points for IFN- $\gamma$, IL-2, and polyfunctional responses never exceeded 13 SFUs/million PBMCs (Supplementary Fig. 3). Therefore, we focused our analysis on $\mathrm{T}$ cells responsive to the $\mathrm{S}, \mathrm{N}$, and $\mathrm{M}$ proteins and the effector functions IFN- $\gamma$ and IL-2.

We observed similar kinetics in the IFN- $\gamma+\mathrm{T}$ cell responses targeting $\mathrm{S}$ and $\mathrm{N}$ between the two treatment groups, with $\mathrm{T}$ cell responses peaking at $\mathrm{D} 7$ followed by a significant reduction by D90+. We did not observe any differences in the magnitude of IFN- $\gamma+\mathrm{T}$ cell responses between 
medRxiv preprint doi: https://doi.org/10.1101/2022.02.24.22271438; this version posted March 3, 2022. The copyright holder for this preprint (which was not certified by peer review) is the author/funder, who has granted medRxiv a license to display the preprint in perpetuity. It is made available under a CC-BY-NC-ND 4.0 International license .

placebo- and PEG-IFN- $\lambda$-treated patients (Fig. 2A). M-specific IFN- $\gamma$ responses did not change over time (Fig. 3A). IL-2+ T cell responses followed a similar trend, peaking at D7 and declining by D90+. In contrast to IFN- $\gamma$, M-specific IL-2 responses increased between D0 and D7 in both groups, and the increase between D0 and D90+ was maintained in PEG-IFN- $\lambda$-treated patients (Fig. 3B). No significant differences in the magnitude of IL-2+ T cell responses were observed between placebo and PEG-IFN- $\lambda$-treated patients. Polyfunctional responses followed the same profile as individual cytokines, peaking at D7 for all SARS-CoV-2 antigens with no significant differences between placebo- and PEG-IFN- $\lambda$-treated groups (Fig. 3C). In addition to the lack of differences in the magnitude of $\mathrm{T}$ cell responses between patient groups, we did not observe differences in the proportion of patients with a positive response between placebo- and PEG-IFN$\lambda$-treated patients at the three time points (Supplementary Fig. 1). We also noted no differences in the breadth of responses in the two groups, with both groups showing similar proportions of antigen-specific responses at the three time points. There was no significant difference in the time between symptom onset and enrollment between the patient groups (Supplementary Fig. 4).

Since $\mathrm{T}$ cell responses aid in $\mathrm{B}$ cell responses, we determined if $\mathrm{T}$ cell cytokine data correlated with RBD-specific antibody production. We found significant correlations between the interferon-gamma (IFN- $\gamma$ ), interleukin-2 (IL-2), and polyfunctional (IFN- $\gamma+\&$ IL-2+) spikespecific $\mathrm{T}$ cell responses and RBD-IgG and $\operatorname{IgA}$ levels at D90+, but not at D0 or D7 (Supplementary Table 4). RBD-specific IgM antibody levels and spike-specific T cell responses did not significantly correlate at any time point (Supplementary Table 4).

Overall, these results indicate that although COVID-19 patients in our trial mounted T cell responses to multiple SARS-CoV-2 proteins, PEG-IFN- $\lambda$ treatment had no effect on the magnitude or functionality of virus-specific $\mathrm{T}$ cell responses over time. 
medRxiv preprint doi: https://doi.org/10.1101/2022.02.24.22271438; this version posted March 3, 2022. The copyright holder for this preprint (which was not certified by peer review) is the author/funder, who has granted medRxiv a license to display the preprint in perpetuity.

It is made available under a CC-BY-NC-ND 4.0 International license .

\section{SARS-CoV-2-specific T cell responses were delayed in older patients}

Having observed that PEG-IFN- $\lambda$ treatment did not impact the magnitude or kinetics of the $\mathrm{T}$ cell response in patients, we investigated additional demographic variables associated with severe COVID-19 disease. During the course of the pandemic, older COVID-19 patients have been found to be at an increased risk of severe complications and death ${ }^{24-28}$. To determine if these observed outcomes may be attributed to virus-specific T cell responses, we compared SARS-CoV2-specific $\mathrm{T}$ cell responses between patients below and above the median age of the cohort (median age $=45, \mathrm{n}=19$ for both groups). We found that older patients had significantly reduced responses towards S and N proteins at D0. The median IFN- $\gamma$ SFUs/million PBMCs towards S protein at D0 was 41.6 in older patients, compared to 323.0 in younger patients $(p=0.0080$, Fig. $4 A)$. The median responses towards the $\mathrm{N}$ protein at D0 in older patients was 5.88 and 173.2 in younger patients $(p=0.0009$, Fig. 4A). Notably, older patients had a similar number of M-specific IFN- $\gamma$ SFUs as the younger group at D0 $(\mathrm{p}=0.23$, Fig. 4A). Similar trends were seen with IL-2 and polyfunctional SFUs between older and younger patients towards S, N, and M proteins at D0. From D7 onwards, these differences were no longer detected with $\mathrm{T}$ cell responses equalized between older and younger patients. However, D90+ M-specific IL-2 and polyfunctional responses were higher in older patients $(p=0.0348$ and $p=0.0491$, respectively, Fig. 4B-C). In the trial, 5 patients ( 4 placebo and 1 PEG-IFN- $\lambda$ ) required emergency room care or hospitalization, all of whom were above age 45 . There were no differences in time from symptom onset to enrollment or baseline viral load, between age groups (Supplementary Fig. 5). The impact of age was specific to the T cell compartment as no significant differences in total or RBD-specific IgG, IgM or IgA levels were observed between those younger or older than 45 years (Supplementary 
medRxiv preprint doi: https://doi.org/10.1101/2022.02.24.22271438; this version posted March 3, 2022. The copyright holder for this preprint (which was not certified by peer review) is the author/funder, who has granted medRxiv a license to display the preprint in perpetuity. It is made available under a CC-BY-NC-ND 4.0 International license .

Fig. 6). The acceleration of viral decline with PEG-IFN- $\lambda$ compared to placebo was not affected by age (OR 0.97, 95\% CI 0.93-1.02).

We also assessed patient characteristics such as sex and the IFNL4 genotype, which have been associated with more severe COVID-19 outcomes $^{29-33}$. No differences in SARS-CoV-2specific $\mathrm{T}$ cell responses were found by sex or IFNL4 genotype (Supplementary Fig. $7 \& 8$ ). Although there were differences in antibody levels by sex and IFNL4 genotype, a clear pattern was not observed (Supplementary Fig. $9 \& 10$ ). Our data suggest that age, but not sex or IFNL4 genotype, negatively impacts development of the SARS-CoV-2-specific T cell response.

Older COVID-19 patients have less diverse IFN- $\gamma$ T cell responses to SARS-CoV-2 in early infection

To better understand the impact of age on the delayed $\mathrm{T}$ cell response, we aggregated responses to SARS-CoV-2 proteins for each patient and arranged patients based on age (left to right on graphs) for each time point tested. For IFN- $\gamma$ responses at D0, younger patients displayed a greater diversity in their T cell repertoire, targeting all three SARS-CoV-2 proteins whereas older patient responses were largely directed towards the membrane protein. Quantitatively, 16/19 $(84.2 \%)$ of older patients attributed more than half of their total IFN- $\gamma$ responses to membrane protein alone at D0. Meanwhile, only 6/19 (31.6\%) of younger patients shared this result $(\mathrm{p}=$ 0.0031, Fig. 5A). By D7, T cell diversity expanded in older patients and only 9/15 (60\%) patients displayed a dominant $\mathrm{M}$ response, which was not significantly different from younger patients $(5 / 18(27.8 \%) ; p=0.1307$, Fig. $5 \mathrm{~A})$. IFN- $\gamma$ response to $\mathrm{S}$ and $\mathrm{N}$ contracted in all patients by D90+ and the overall response was dominated by $\mathrm{M}$ at this timepoint. 
medRxiv preprint doi: https://doi.org/10.1101/2022.02.24.22271438; this version posted March 3, 2022. The copyright holder for this preprint (which was not certified by peer review) is the author/funder, who has granted medRxiv a license to display the preprint in perpetuity.

It is made available under a CC-BY-NC-ND 4.0 International license .

IL-2 responses showed a different antigen-specific distribution and even greater differences in magnitude based on age. The majority of IL-2+ responses were directed towards S and $\mathrm{N}$ and the magnitude of IL-2 responses was clearly higher in younger patients at D0 (Fig. 5B). Similar to IFN- $\gamma$, at D7 IL-2+ T cells became detectable in the older patients, also primarily targeting the $\mathrm{S}$ and $\mathrm{N}$ proteins. However, unlike IFN- $\gamma$, IL-2+ responses at $\mathrm{D} 90+$ remained distributed between $\mathrm{S}$ and N, with M-specific T cells contributing less to the overall IL-2 response (Fig. 5B). The polyfunctional T cell response followed the same pattern as observed for IL-2 (Fig. 5C). Together our findings show that the early IFN- $\gamma+$ antigen-specific $\mathrm{T}$ cell repertoire differed significantly by age and that early IL-2 responses, critical for T cell function, were significantly reduced in magnitude in older patients.

\section{Discussion}

Our clinical trial data demonstrated that a single subcutaneous injection of PEG-IFN- $\lambda$ $(180 \mu \mathrm{g})$ showed efficacy as an early antiviral treatment for COVID-19. Here, we show that specific immune cells in the peripheral blood were responsive to PEG-IFN- $\lambda$, but this responsiveness did not modulate adaptive immunity to SARS-CoV-2, either positively or negatively. However, early sampling revealed that older patients displayed a delayed $\mathrm{T}$ cell response towards SARS-CoV-2, showing a less diverse and less functional early response. Overall, our findings show that accelerated clearance of SARS-CoV-2 by PEG-IFN- $\lambda$ was mediated by induction of the antiviral ISG response without major effects on B and $\mathrm{T}$ cell immunity, an advantage in older patients where the $\mathrm{T}$ cell immune response was delayed. 
medRxiv preprint doi: https://doi.org/10.1101/2022.02.24.22271438; this version posted March 3, 2022. The copyright holder for this preprint (which was not certified by peer review) is the author/funder, who has granted medRxiv a license to display the preprint in perpetuity. It is made available under a CC-BY-NC-ND 4.0 International license .

Our results revealed that subsets of immune cells within PBMCs expressed IFNLRI and were able to respond to PEG-IFN- $\lambda$ in vivo by upregulating ISGs. Our in vivo results are in agreement with earlier studies demonstrating IFN- $\lambda$ responsiveness in vitro, with pDCs and B cells as the top responders and monocytes and natural killer cells as non-responders ${ }^{20,23}$. Subsets of CD8+ T cells, despite expressing IFNLR1, did not respond to PEG-IFN- $\lambda$ in vivo. This is in contrast to our previous results where in vitro IFN- $\lambda 3$ treatment of healthy donor CD8+ T cells led to an upregulation of antiviral ISGs measured by reverse transcription quantitative real-time PCR $(\mathrm{RT}-\mathrm{qPCR})^{20}$. Deeper analysis of the IFNLR1+ CD8 T cells revealed relatively low expression levels for both receptor chains (not shown), which may induce a response that falls below the sensitivity of scRNAseq. We also noted high baseline ISG expression in all patients. This was not unexpected due to the acute virus infection, but likely limited the magnitude of ISG induction upon PEG-IFN- $\lambda$ treatment. Overall, our in vivo data match previous in vitro studies and demonstrate that immune cells respond to IFN- $\lambda$ in vivo despite an ongoing SARS-CoV-2 infection.

Similar to previous reports, we detected virus-specific $\mathrm{T}$ cell responses in acute and convalescent COVID-19 patients targeting SARS-CoV-2 structural proteins, including spike, nucleocapsid, and membrane ${ }^{34-39}$. Spike- and nucleocapsid-specific $\mathrm{T}$ cells dominated the $\mathrm{T}$ cell response, peaking at D7 and displaying the broadest functionality. Membrane-specific T cells displayed different kinetics for IFN- $\gamma$, with detectable responses at D0 that did not change significantly over time. PEG-IFN- $\lambda$ treatment had no impact on the kinetics, magnitude, functionality, or maintenance of a functional memory $\mathrm{T}$ cell pool compared to placebo. However, age, a key variable associated with severe COVID-19 disease outcomes, impacted the generation of SARS-CoV-2-specific T cell immunity ${ }^{28,43-45}$. Both IFN- $\gamma$ and IL-2 responses were significantly delayed in patients over 45 years old. Notably all 5 patients in the trial who required hospitalization 
medRxiv preprint doi: https://doi.org/10.1101/2022.02.24.22271438; this version posted March 3, 2022. The copyright holder for this preprint (which was not certified by peer review) is the author/funder, who has granted medRxiv a license to display the preprint in perpetuity.

It is made available under a CC-BY-NC-ND 4.0 International license .

were over this age threshold. Our data are consistent with a recent report showing impaired naïve CD8+ T cell priming in older patients ${ }^{46,47}$. Other studies have also assessed age-related differences in $\mathrm{T}$ cell responses, observing decreased cytotoxic CD8+ responses and lower IFN- $\gamma /$ higher IL-2 secreting CD4+ T cells in older patients ${ }^{48,49}$. However, these studies either had a lower number of participants or recruited participants during a wide range of time after symptom onset. A strength of our study was baseline samples were collected within 7 days of symptom onset in patients with a laboratory-confirmed diagnosis, providing better insight into the immune response early in the infection. Altogether, our findings show delayed $\mathrm{T}$ cell responses early after infection in older individuals, potentially exposing them to greater severity of outcomes, which may be compensated by early therapeutic intervention with PEG-IFN- $\lambda$.

Given our previous study showed in vitro exposure to IFN- $\lambda$ negatively impacted influenza vaccine antibody responses ${ }^{22}$, we anticipated a negative impact on antibody production. However, despite detecting $\mathrm{B}$ cells were responsive to PEG-IFN- $\lambda$ in peripheral blood, no difference in the levels of RBD-specific IgM, IgA, or IgG were measured in patient plasma between placebo and PEG-IFN- $\lambda$ groups. This indicates that one dose of PEG-IFN- $\lambda$ was not sufficient to alter systemic antibody levels. RBD-specific IgG antibodies were still elevated above baseline in most patients at D90+, indicating long-term circulating levels in plasma. Unlike $\mathrm{T}$ cell responses, there was no significant impact of age on antibody levels. Age has been negatively correlated with SARS-CoV2 antibody levels, although greatest differences have been documented in those over $60^{50,51}$. Whether multiple injections of PEG-IFN- $\lambda$ could impact B cell function or responses by age, or whether memory B cell persistence and function at mucosal sites were altered requires further investigation. 
medRxiv preprint doi: https://doi.org/10.1101/2022.02.24.22271438; this version posted March 3, 2022. The copyright holder for this preprint (which was not certified by peer review) is the author/funder, who has granted medRxiv a license to display the preprint in perpetuity. It is made available under a CC-BY-NC-ND 4.0 International license .

We also assessed sex and IFNL4 genotype during our analysis since both have been associated with COVID-19 disease outcomes ${ }^{29-33}$. Multiple groups have found a greater proportion of male patients suffer from more severe COVID-19 outcomes ${ }^{29-31}$. While we did not find sex differences in $\mathrm{T}$ cell responses in our patient cohort, we were able to see some significant differences in antibody levels (i.e., Total IgM and RBD-specific IgA) but the relevance of these differences remains unclear. In chronic hepatitis $\mathrm{C}$ virus infections, IFNL4 genotype has been found to negatively affect the efficacy of PEG-IFN- $\alpha$ treatment and the probability of spontaneous viral clearance in those with the $\Delta \mathrm{G}$ rs368234815 genotype ${ }^{52-54}$. Similar to our findings, a recent study found no associations with SARS-CoV-2-specific CD8+ T cell responses or antibody levels and IFNL4 genotype ${ }^{55}$. However, IFNL4 variants have been found to be associated with the severity of and predisposition to acquiring COVID-19 32,33 , suggesting that IFNL4 genotype may affect innate immune responses, rather than adaptive responses. Of the 5 patients in our cohort who required hospital care, 4 had the risk-associated genotype at rs368234815. Additional analyses of the effects of sex and IFNL4 genotype on SARS-CoV-2-specific T cell and antibody responses would be useful, as our findings are limited by small sample size.

To summarize, our analyses demonstrate that a single dose of PEG-IFN- $\lambda$ accelerates viral clearance without affecting virus-specific $\mathrm{T}$ cell responses or antibody production in mild-tomoderate acute SARS-CoV-2 infection. Compared to current antiviral treatments for COVID-19, PEG-IFN- $\lambda$ treatment is broad-acting, effective with a single dose, and is unlikely to be affected by new variants or resistance mutations. This supports future use of PEG-IFN- $\lambda$ as an early treatment option because it provides beneficial antiviral effects without negative consequences on adaptive immunity. This aspect may be particularly relevant for older COVID-19 patients who may have naturally delayed $\mathrm{T}$ cell responses to SARS-CoV-2 early in an infection. 
medRxiv preprint doi: https://doi.org/10.1101/2022.02.24.22271438; this version posted March 3, 2022. The copyright holder for this preprint (which was not certified by peer review) is the author/funder, who has granted medRxiv a license to display the preprint in perpetuity.

It is made available under a CC-BY-NC-ND 4.0 International license .

\section{Methods}

\section{Ethical Statement \& Human Subjects}

Subjects were recruited for a randomised, double-blind, placebo-controlled study from outpatient testing centers at six institutions in Toronto, Canada. Eligible individuals had a SARS-CoV-2 infection confirmed by nasopharyngeal swab and were enrolled within 7 days of symptom onset or first positive test if asymptomatic. The research ethics boards of all participating institutions approved the study, which was registered (NCT04354259) and done under a Clinical Trial Application approved by Health Canada. All participants provided written informed consent. Additional trial information is detailed in Feld et al. $(2021)^{11}$.

\section{Plasma Collection and PBMC Isolation}

Freshly collected blood samples in acid citrate dextrose (ACD) tubes were centrifuged and plasma was frozen and stored in $-80^{\circ} \mathrm{C}$. Remaining whole blood was used for PBMC isolation, using SepMate PBMC Isolation Tubes and the Lymphoprep density gradient medium (STEMCELL Technologies). Isolation was conducted according to the manufacturer's instructions. PBMCs were subsequently frozen at $-80^{\circ} \mathrm{C}$ overnight and stored in liquid nitrogen for long-term storage.

PBMC scRNAseq

PBMCs were thawed quickly at $37^{\circ} \mathrm{C}$ and washed to remove freezing media. Pelleted cells were resuspended in PBS $+0.1 \%$ low endotoxin BSA and counted using $0.4 \%$ Trypan blue solution (Thermo Fisher Scientific). Samples had average of $87 \%$ viability after thawing. Cells were resuspended in $\mathrm{PBS}+0.1 \%$ low endotoxin $\mathrm{BSA}$ in an appropriate volume to achieve a 
medRxiv preprint doi: https://doi.org/10.1101/2022.02.24.22271438; this version posted March 3, 2022. The copyright holder for this preprint (which was not certified by peer review) is the author/funder, who has granted medRxiv a license to display the preprint in perpetuity. It is made available under a CC-BY-NC-ND 4.0 International license .

concentration of 1000 cells $/ \mathrm{ml}$. This cell suspension was used to generate the gel-beads + cell emulsion by the 10X Chromium Controller (PN-1000202) using the Chromium Next GEM Single Cell 5' v2, Chromium Next GEM Chip K Single Cell Kit and Dual Index Kit TT Set A. Reverse transcription, cDNA amplification, library preparation, and sample barcoding were performed following the available manufacturer's protocol. Finally, sample libraries were pooled and sequenced in Illumina HiSeq P150 (Sequencing type: Paired-end, single indexing) to an average depth of $\sim 35,261$ reads per cell (Novogene).

\section{Preprocessing and analysis of scRNA-seq data}

FASTQ files were inputted to 10X Genomics Cell Ranger 6.0.0 count tool with default parameters and mapped to the human reference GRCh38-2020 also provided by $10 \mathrm{X}^{56}$. Afterwards, the filtered matrix files output by Cell Ranger count tool was used with the aggr tool in Cell Ranger with default parameters. Aggregated expression matrix for all cells was analyzed with the Seurat v4.0.4 R package ${ }^{57}$. Briefly, genes which were expressed in less than 100 cells were discarded. Low quality cells with less than 500 genes or cells with high $(>=15 \%)$ mitochondrial content were filtered out. Furthermore, doublet cells were identified through scDblFinder v1.7.4 ${ }^{58}$. Standard Seurat pipeline was run with 5000 variable features retained and 50 principal components (PCs) used for downstream analysis. In addition, Harmony v0.1.0 was used for batch effect correction due to sequencing batch and $\operatorname{sex}^{59}$. Number of neighbors for both UMAP projection and SNN network was set at 50. Finally, 0.8 was set as the resolution for the Louvain neighborhood detection. After this first-pass analysis, all clusters which had more than $50 \%$ of cells classified as doublets were discarded along with cells that were classified as doublets. The filtered dataset was run through Seurat again with the same parameters as previously set. 
medRxiv preprint doi: https://doi.org/10.1101/2022.02.24.22271438; this version posted March 3, 2022. The copyright holder for this preprint (which was not certified by peer review) is the author/funder, who has granted medRxiv a license to display the preprint in perpetuity.

It is made available under a CC-BY-NC-ND 4.0 International license .

Differentially expressed genes were identified using "FindMarkers" from Seurat with parameters (latent.vars=c("Batch","Sex","nFeature_RNA"), test.use="LR").

ISG scoring and visualization

ISG score for each cell was calculated according to Seurat function "AddModuleScore" with default parameters. The list of ISGs which were used to compute the score are in Supplementary Table 1. Due to the variability of the scores between patients and by baseline viral load, we calculated the change of ISG score compared to D0. Panel generation and compilation was done through R packages (ggplot2 v3.3.5, ggrepel v0.9.1, patchwork v1.1.1, dplyr v1.0.7, reshape2 v1.4.4) ${ }^{60-64}$.

\section{Total and SARS-CoV-2-specific antibody ELISAs}

All plasma was heat-inactivated at $56^{\circ} \mathrm{C}$ for $45 \mathrm{~min}$ before diluting for ELISA. Total IgG and IgM in plasma were measured via an in-house ELISA with standards and antibodies from Jackson Immunoresearch. Total IgA measurements were quantified using an ELISA kit from STEMCELL Technologies. Our SARS-CoV-2 RBD-ELISA was optimized based on a study by Amanat et al. (2020) ${ }^{65}$ using purified spike RBD (wild-type) supplied as a gift from the lab of Dr. Michael Houghton (University of Alberta). 96-well plates (Corning 96-well EIA/RIA Easy Wash $\left.{ }^{\mathrm{TM}}\right)$ were coated overnight at $4^{\circ} \mathrm{C}$ with $50 \mathrm{ul} \mathrm{RBD}(1.5 \mathrm{ug} / \mathrm{ml})$ in PBS. After washing, wells were blocked with 3\% non-fat milk in PBS for 2 hrs at room temperature. Optimal dilutions were determined balancing background and detection limits where the final dilutions chosen were 1:100 for IgG, 1:40 for IgM and 1:40 for IgA. Plasma was diluted in 1\% non-fat milk in PBS. Secondary 
medRxiv preprint doi: https://doi.org/10.1101/2022.02.24.22271438; this version posted March 3, 2022. The copyright holder for this preprint (which was not certified by peer review) is the author/funder, who has granted medRxiv a license to display the preprint in perpetuity. It is made available under a CC-BY-NC-ND 4.0 International license.

antibodies (goat anti-human Ig alkaline phosphatase) were from Jackson Immunoresearch (antihuman IgG, IgM) or Thermo Fisher Scientific (anti-human IgA) and PNPP substrate was from Thermo Fisher Scientific. 8 pre-pandemic plasma samples collected in 2018 or earlier were used to determine a baseline background (shown as dotted line on graphs). One positive control was run on each plate to normalize readings between plates.

\section{Peptide Pools}

12- to 15-mer peptides overlapping with 10 amino acids residues spanning the full sequences of the wild-type SARS-CoV-2 membrane (M), envelope (E), nucleocapsid (N), and spike (S) proteins were used to stimulate PBMCs (BEI Resources). Peptides were reconstituted with $20 \mathrm{uL}$ of DMSO $(50 \mathrm{mg} / \mathrm{mL})$ and pooled to form 8 peptide pools. A peptide pool made up of epitopes from cytomegalovirus, Epstein-Barr virus, and influenza virus (CEF) was used as a positive control and contained 32 peptides. 
medRxiv preprint doi: https://doi.org/10.1101/2022.02.24.22271438; this version posted March 3, 2022. The copyright holder for this preprint (which was not certified by peer review) is the author/funder, who has granted medRxiv a license to display the preprint in perpetuity.

It is made available under a CC-BY-NC-ND 4.0 International license .

\begin{tabular}{|c|c|c|c|}
\hline Protein & $\begin{array}{l}\text { Peptide } \\
\text { Pool } \\
\text { Name }\end{array}$ & $\begin{array}{l}\text { \# of } \\
\text { peptides }\end{array}$ & Pool Length \\
\hline Membrane & $\mathrm{M}$ & 31 & $1-222$ \\
\hline Envelope & $\mathrm{E}$ & 10 & $1-75$ \\
\hline Nucleocapsid & $\begin{array}{l}\text { N1 } \\
\text { N2 }\end{array}$ & $\begin{array}{l}30 \\
29\end{array}$ & $\begin{array}{l}1-220 \\
211-419\end{array}$ \\
\hline Spike & $\begin{array}{l}\text { S1 } \\
\text { S2 } \\
\text { S3 } \\
\text { S4 }\end{array}$ & $\begin{array}{l}45 \\
45 \\
45 \\
46\end{array}$ & $\begin{array}{l}1-325 \\
316-640 \\
631-955 \\
946-1273\end{array}$ \\
\hline
\end{tabular}

\section{PBMC Stimulation \& Fluorospot}

PBMCs were thawed at $37^{\circ} \mathrm{C}$, washed with Hanks' Balanced Salt Solution and resuspended in AIM V treated with primocin (Life Technologies). 300,000 PBMCs were added in duplicates to each well on a 96-well fluorospot plate and treated with peptide pools at a concentration of 5 $\mathrm{ug} / \mathrm{mL}$ for $24 \mathrm{~h}$ at $37^{\circ} \mathrm{C}$. In some instances, 200,000 PBMCs were plated. The negative control consisted of $0.46 \%$ DMSO, which is the highest concentration of DMSO cells in the peptide treated wells were exposed to. Positive controls consisted of anti-CD3/CD28 beads (Dynabeads; Thermo Fisher Scientific) and a CEF peptide pool (GenScript, $5 \mathrm{ug} / \mathrm{mL}$ ). T cell responses were measured using a 3-colour FluoroSpot assay (Cellular Technology Limited (CTL) ImmunoSpot) measuring human IFN- $\gamma$ (green), IL-2 (yellow), and GzmB (red) secretion. Assays were conducted according to the manufacturer's instructions. Plates were scanned using the CTL ImmunoSpot S6 Analyzer. 
medRxiv preprint doi: https://doi.org/10.1101/2022.02.24.22271438; this version posted March 3, 2022. The copyright holder for this preprint (which was not certified by peer review) is the author/funder, who has granted medRxiv a license to display the preprint in perpetuity.

It is made available under a CC-BY-NC-ND 4.0 International license .

Spot forming units (SFUs) were counted using ImmunoSpot Software. All SFU counts were normalized by subtracting the background DMSO-stimulated SFU count of the individual patient time point.

\section{IFNL4 Genotyping}

The interferon lambda-4 genotype (IFNL4) was assessed by sequencing rs368234815 in genomic DNA from whole blood. Briefly, the genomic DNA was extracted from whole blood using QIAamp DNA Blood Kit (Qiagen, Canada) according to the manufacturer's instructions. The extracted DNA was amplified using 5'- GCACTGCAGACAGGAGTGAG -3' and 5'TCGTAGCGGTCCCTCAG-3' as forward and reverse primers, respectively. Purified PCR amplicons were directly sequenced using 5'-GACGTCTCTCGCCTGCT-3' as a sequencing primer by Sanger method to determine the genotype which was categorized as TT or non-TT (_G/T or_G/_G) $)^{52-54}$.

\section{Statistical Analysis}

Data between time points were compared using paired Wilcoxon t-tests with patients missing measurements for time points excluded from analysis. Data between patient treatment groups (placebo versus PEG-IFN- $\lambda$ ) were compared using Mann-Whitney U tests. Correlation analysis was conducted using non-parametric, Spearman rank correlation tests. Chi-square tests with Yates' correction were conducted for comparing the proportion of positive responses between treatment groups and the proportion of individuals with high membrane responses between age groups. Statistical analysis was conducted on GraphPad Prism version 9.3 and R v4.1.1. 
medRxiv preprint doi: https://doi.org/10.1101/2022.02.24.22271438; this version posted March 3, 2022. The copyright holder for this preprint (which was not certified by peer review) is the author/funder, who has granted medRxiv a license to display the preprint in perpetuity. It is made available under a CC-BY-NC-ND 4.0 International license.

Significant differences are labelled as $*, p<0.05 ; * *, p<0.01 ; * * *, p<0.001 ; * * * *, p<0.0001$. Insignificant differences remain unlabelled.

\section{Acknowledgments}

We thank Joaquín López-Orozco and Karyn Berry-Wynne from the University of Alberta High Content Analysis core facility and Tyrrell lab, respectively, for their assistance with preparing the 10x genomic libraries. We thank Julia Casey, Conan Chua, and the clinical team at the Toronto Centre for Liver Disease for their assistance with sample collection, preparation, and method support. Thank you to Dr. Michael Houghton for the kind gift of recombinant SARS-CoV2 spike RBD protein.

\section{Funding}

The Toronto COVID-19 Action Initiative (JJF), CIHR operating grant (COVID-19 Rapid Research Funding Opportunity) (DLT, JJF), University of Toronto (JJF), Ontario First COVID-19 Rapid Research Fund (JJF), Toronto General (JJF), Western Hospital Foundation (JJF) and University of Manitoba start-up funding (DS). 
medRxiv preprint doi: https://doi.org/10.1101/2022.02.24.22271438; this version posted March 3, 2022. The copyright holder for this preprint (which was not certified by peer review) is the author/funder, who has granted medRxiv a license to display the preprint in perpetuity.

It is made available under a CC-BY-NC-ND 4.0 International license .

\section{References}

1. Torjesen, I. Covid-19 will become endemic but with decreased potency over time, scientists believe. BMJ 372, n494 (2021).

2. Crosse, K. M., Monson, E. A., Beard, M. R. \& Helbig, K. J. Interferon-Stimulated Genes as Enhancers of Antiviral Innate Immune Signaling. J Innate Immun 10, 85-93 (2018).

3. Masood, K. I. et al. Upregulated type I interferon responses in asymptomatic COVID-19 infection are associated with improved clinical outcome. Sci Rep 11, 22958 (2021).

4. Bastard, P. et al. Auto-antibodies to type I IFNs can underlie adverse reactions to yellow fever live attenuated vaccine. $J$ Exp Med 218, (2021).

5. Zhang, Q. et al. Inborn errors of type I IFN immunity in patients with life-threatening COVID-19. Science (2020) doi:10.1126/science.abd4570.

6. Troya, J. et al. Neutralizing Autoantibodies to Type I IFNs in $>10 \%$ of Patients with Severe COVID-19 Pneumonia Hospitalized in Madrid, Spain. J Clin Immunol 41, 914-922 (2021).

7. Hayn, M. et al. Systematic functional analysis of SARS-CoV-2 proteins uncovers viral innate immune antagonists and remaining vulnerabilities. Cell Rep 35, 109126 (2021).

8. Xia, H. et al. Evasion of Type I Interferon by SARS-CoV-2. Cell Rep 33, 108234 (2020).

9. Lei, X. et al. Activation and evasion of type I interferon responses by SARS-CoV-2. Nature Communications 11, 3810 (2020).

10. Shemesh, M. et al. SARS-CoV-2 suppresses IFN $\beta$ production mediated by NSP1, 5, 6, 15, ORF6 and ORF7b but does not suppress the effects of added interferon. PLoS Pathog 17, e1009800 (2021). 
medRxiv preprint doi: https://doi.org/10.1101/2022.02.24.22271438; this version posted March 3, 2022. The copyright holder for this preprint (which was not certified by peer review) is the author/funder, who has granted medRxiv a license to display the preprint in perpetuity. It is made available under a CC-BY-NC-ND 4.0 International license .

11. Feld, J. J. et al. Peginterferon lambda for the treatment of outpatients with COVID-19: a phase 2, placebo-controlled randomised trial. The Lancet Respiratory Medicine 9, 498-510 (2021).

12. Vanderheiden, A. et al. Type I and Type III Interferons Restrict SARS-CoV-2 Infection of Human Airway Epithelial Cultures. J Virol 94, e00985-20 (2020).

13. Sohn, S.-Y. et al. Interferon-Lambda Intranasal Protection and Differential Sex Pathology in a Murine Model of SARS-CoV-2 Infection. mBio e0275621 (2021) doi:10.1128/mBio.02756-21.

14. Hemann, E. A., Gale, M. \& Savan, R. Interferon Lambda Genetics and Biology in Regulation of Viral Control. Front Immunol 8, 1707 (2017).

15. Lazear, H. M., Nice, T. J. \& Diamond, M. S. Interferon- $\lambda$ : Immune Functions at Barrier Surfaces and Beyond. Immunity 43, 15-28 (2015).

16. Kotenko, S. V. et al. IFN-lambdas mediate antiviral protection through a distinct class II cytokine receptor complex. Nat Immunol 4, 69-77 (2003).

17. Sheppard, P. et al. IL-28, IL-29 and their class II cytokine receptor IL-28R. Nat Immunol 4, 63-68 (2003).

18. Forero, A. et al. Differential Activation of the Transcription Factor IRF1 Underlies the Distinct Immune Responses Elicited by Type I and Type III Interferons. Immunity 51, 451464.e6 (2019).

19. Davidson, S. et al. IFN $\lambda$ is a potent anti-influenza therapeutic without the inflammatory side effects of IFN $\alpha$ treatment. EMBO Mol Med 8, 1099-1112 (2016). 
medRxiv preprint doi: https://doi.org/10.1101/2022.02.24.22271438; this version posted March 3, 2022. The copyright holder for this preprint (which was not certified by peer review) is the author/funder, who has granted medRxiv a license to display the preprint in perpetuity. It is made available under a CC-BY-NC-ND 4.0 International license .

20. Santer, D. M. et al. Differential expression of interferon-lambda receptor 1 splice variants determines the magnitude of the antiviral response induced by interferon-lambda 3 in human immune cells. PLOS Pathogens 16, e1008515 (2020).

21. Jordan, W. J. et al. Human interferon lambda-1 (IFN-lambda1/IL-29) modulates the Th1/Th2 response. Genes Immun 8, 254-261 (2007).

22. Egli, A. et al. IL-28B is a key regulator of B- and T-cell vaccine responses against influenza. PLoS Pathog 10, e1004556 (2014).

23. Yin, Z. et al. Type III IFNs are produced by and stimulate human plasmacytoid dendritic cells. J Immunol 189, 2735-2745 (2012).

24. Yang, X. et al. Clinical course and outcomes of critically ill patients with SARS-CoV-2 pneumonia in Wuhan, China: a single-centered, retrospective, observational study. The Lancet Respiratory Medicine 8, 475-481 (2020).

25. Zhou, F. et al. Clinical course and risk factors for mortality of adult inpatients with COVID-19 in Wuhan, China: a retrospective cohort study. The Lancet 395, 1054-1062 (2020).

26. Wu, C. et al. Risk Factors Associated With Acute Respiratory Distress Syndrome and Death in Patients With Coronavirus Disease 2019 Pneumonia in Wuhan, China. JAMA Internal Medicine 180, 934-943 (2020).

27. Du, R.-H. et al. Predictors of mortality for patients with COVID-19 pneumonia caused by SARS-CoV-2: a prospective cohort study. European Respiratory Journal 55, (2020).

28. Brunet-Ratnasingham, E. et al. Integrated immunovirological profiling validates plasma SARS-CoV-2 RNA as an early predictor of COVID-19 mortality. Science Advances 7, eabj5629. 
medRxiv preprint doi: https://doi.org/10.1101/2022.02.24.22271438; this version posted March 3, 2022. The copyright holder for this preprint (which was not certified by peer review) is the author/funder, who has granted medRxiv a license to display the preprint in perpetuity. It is made available under a CC-BY-NC-ND 4.0 International license .

29. Huang, B. et al. Sex-based clinical and immunological differences in COVID-19. BMC Infectious Diseases 21, 647 (2021).

30. Jin, J.-M. et al. Gender Differences in Patients With COVID-19: Focus on Severity and Mortality. Frontiers in Public Health 8, 152 (2020).

31. Peckham, H. et al. Male sex identified by global COVID-19 meta-analysis as a risk factor for death and ITU admission. Nat Commun 11, 6317 (2020).

32. Saponi-Cortes, J. M. R. et al. IFNL4 genetic variant can predispose to COVID-19. Sci Rep 11, 21185 (2021).

33. Rahimi, P. et al. The association between interferon lambda 3 and 4 gene singlenucleotide polymorphisms and the recovery of COVID-19 patients. Virol J 18, 221 (2021).

34. Peng, Y. et al. Broad and strong memory CD4 + and CD8 + T cells induced by SARSCoV-2 in UK convalescent individuals following COVID-19. Nature Immunology 1-10 (2020) doi:10.1038/s41590-020-0782-6.

35. Keller, M. D. et al. SARS-CoV-2 specific T-cells Are Rapidly Expanded for Therapeutic Use and Target Conserved Regions of Membrane Protein. Blood blood.2020008488 (2020) doi:10.1182/blood.2020008488.

36. Kroemer, M. et al. COVID-19 patients display distinct SARS-CoV-2 specific T-cell responses according to disease severity. Journal of Infection $\mathbf{0},(2020)$.

37. Grifoni, A. et al. Targets of T Cell Responses to SARS-CoV-2 Coronavirus in Humans with COVID-19 Disease and Unexposed Individuals. Cell 181, 1489-1501.e15 (2020).

38. Braun, J. et al. SARS-CoV-2-reactive T cells in healthy donors and patients with COVID-19. Nature 1-8 (2020) doi:10.1038/s41586-020-2598-9. 
medRxiv preprint doi: https://doi.org/10.1101/2022.02.24.22271438; this version posted March 3, 2022. The copyright holder for this preprint (which was not certified by peer review) is the author/funder, who has granted medRxiv a license to display the preprint in perpetuity. It is made available under a CC-BY-NC-ND 4.0 International license .

39. Zuo, J. et al. Robust SARS-CoV-2-specific T cell immunity is maintained at 6 months following primary infection. Nature Immunology 22, 620-626 (2021).

40. Koltsida, O. et al. IL-28A (IFN- $\lambda 2$ ) modulates lung DC function to promote Th1 immune skewing and suppress allergic airway disease. EMBO Mol Med 3, 348-361 (2011).

41. Broggi, A., Tan, Y., Granucci, F. \& Zanoni, I. IFN- $\lambda$ suppresses intestinal inflammation by non-translational regulation of neutrophil function. Nat Immunol 18, 1084-1093 (2017).

42. Blazek, K. et al. IFN- $\lambda$ resolves inflammation via suppression of neutrophil infiltration and IL-1 $\beta$ production. $J$ Exp Med 212, 845-853 (2015).

43. Shi, C. et al. Predictors of mortality in patients with coronavirus disease 2019: a systematic review and meta-analysis. BMC Infectious Diseases 21, 663 (2021).

44. Mehraeen, E. et al. Predictors of mortality in patients with COVID-19-a systematic review. Eur J Integr Med 40, 101226 (2020).

45. España, P. P. et al. Predictors of mortality of COVID-19 in the general population and nursing homes. Intern Emerg Med 1-10 (2021) doi:10.1007/s11739-020-02594-8.

46. Agrawal, A., Agrawal, S. \& Gupta, S. Role of Dendritic Cells in Inflammation and Loss of Tolerance in the Elderly. Frontiers in Immunology 8, 896 (2017).

47. Gallerani, E. et al. Impaired Priming of SARS-CoV-2-Specific Naive CD8+ T Cells in Older Subjects. Front Immunol 12, 693054 (2021).

48. Sattler, A. et al. SARS-CoV-2-specific T cell responses and correlations with COVID19 patient predisposition. J Clin Invest 130, 6477-6489.

49. Westmeier, J. et al. Impaired Cytotoxic CD8+ T Cell Response in Elderly COVID-19 Patients. mBio 11, e02243-20. 
medRxiv preprint doi: https://doi.org/10.1101/2022.02.24.22271438; this version posted March 3, 2022. The copyright holder for this preprint (which was not certified by peer review) is the author/funder, who has granted medRxiv a license to display the preprint in perpetuity. It is made available under a CC-BY-NC-ND 4.0 International license .

50. Steensels, D., Pierlet, N., Penders, J., Mesotten, D. \& Heylen, L. Comparison of SARSCoV-2 Antibody Response Following Vaccination With BNT162b2 and mRNA-1273. JAMA 326, 1533-1535 (2021).

51. Levin, E. G. et al. Waning Immune Humoral Response to BNT162b2 Covid-19 Vaccine over 6 Months. New England Journal of Medicine 385, e84 (2021).

52. Ge, D. et al. Genetic variation in IL28B predicts hepatitis C treatment-induced viral clearance. Nature 461, 399-401 (2009).

53. Prokunina-Olsson, L. et al. A variant upstream of IFNL3 (IL28B) creating a new interferon gene IFNL4 is associated with impaired clearance of hepatitis C virus. Nat. Genet. 45, 164-171 (2013).

54. Thomas, D. L. et al. Genetic variation in IL28B and spontaneous clearance of hepatitis C virus. Nature 461, 798-801 (2009).

55. Møhlenberg, M. et al. The Impact of IFN $\lambda 4$ on the Adaptive Immune Response to SARSCoV-2 Infection. J Interferon Cytokine Res 41, 407-414 (2021).

56. Zheng, G. X. Y. et al. Massively parallel digital transcriptional profiling of single cells. Nat Commun 8, 14049 (2017).

57. Hao, Y. et al. Integrated analysis of multimodal single-cell data. Cell 184, 3573-3587.e29 (2021).

58. Germain, P.-L. scDblFinder: scDblFinder. (2021).

59. Korsunsky, I. et al. Fast, sensitive and accurate integration of single-cell data with Harmony. Nat Methods 16, 1289-1296 (2019).

60. Wickham, H. ggplot2: Elegant Graphics for Data Analysis. (Springer-Verlag New York, 2016). 
medRxiv preprint doi: https://doi.org/10.1101/2022.02.24.22271438; this version posted March 3, 2022. The copyright holder for this preprint (which was not certified by peer review) is the author/funder, who has granted medRxiv a license to display the preprint in perpetuity. It is made available under a CC-BY-NC-ND 4.0 International license .

61. Slowikowski, K. ggrepel: Automatically Position Non-Overlapping Text Labels with 'ggplot2'. (2021).

62. Pedersen, T. L. patchwork: The Composer of Plots. (2020).

63. Wickham, H., François, R., Henry, L. \& Müller, K. dplyr: A Grammar of Data Manipulation. (2021).

64. Wickham, H. Reshaping Data with the reshape Package. Journal of Statistical Software 21, 1-20 (2007).

65. Amanat, F. et al. A serological assay to detect SARS-CoV-2 seroconversion in humans.

Nat Med 26, 1033-1036 (2020). 
medRxiv preprint doi: https://doi.org/10.1101/2022.02.24.22271438; this version posted March 3, 2022. The copyright holder for this preprint (which was not certified by peer review) is the author/funder, who has granted medRxiv a license to display the preprint in perpetuity. It is made available under a CC-BY-NC-ND 4.0 International license.

Table 1. Patient characteristics for $\mathrm{T}$ cell and antibody analyses.

\begin{tabular}{|c|c|c|c|}
\hline & Placebo & PEG-IFN- $\lambda$ & Total \\
\hline \multicolumn{4}{|l|}{$\mathrm{T}$ cell analysis } \\
\hline Total \# & 17 & 21 & 38 \\
\hline Day 0 & 17 & 21 & 38 \\
\hline Day 7 & 16 & 17 & 33 \\
\hline Day $90+$ & 15 & 19 & 34 \\
\hline \multicolumn{4}{|l|}{ Sex } \\
\hline Female & 7 & 8 & 15 \\
\hline Male & 10 & 13 & 23 \\
\hline $\begin{array}{l}\text { Median age, years (range) } \\
\text { IFNL4 genotype }\end{array}$ & $41(22-63)$ & $47(21-61)$ & $45(21-63)$ \\
\hline G & 0 & 1 & 1 \\
\hline TT/_G & 9 & 9 & 18 \\
\hline $\mathrm{TT}$ & 8 & 11 & 19 \\
\hline \multicolumn{4}{|l|}{ Antibody analysis } \\
\hline \multicolumn{4}{|l|}{ Time Points } \\
\hline Day 0 & 12 & 15 & 27 \\
\hline Day 7 & 12 & 14 & 26 \\
\hline Day $90+$ & 11 & 14 & 25 \\
\hline \multicolumn{4}{|l|}{ Sex } \\
\hline Female & 4 & 8 & 12 \\
\hline Male & 8 & 7 & 15 \\
\hline Median age, years (range) & $45.5(22-62)$ & $42(21-61)$ & $43(21-62)$ \\
\hline \multicolumn{4}{|l|}{ IFNL4 genotype } \\
\hline _G & 0 & 0 & 0 \\
\hline TT/_G & 6 & 7 & 13 \\
\hline $\mathrm{TT}$ & 6 & 8 & 14 \\
\hline
\end{tabular}




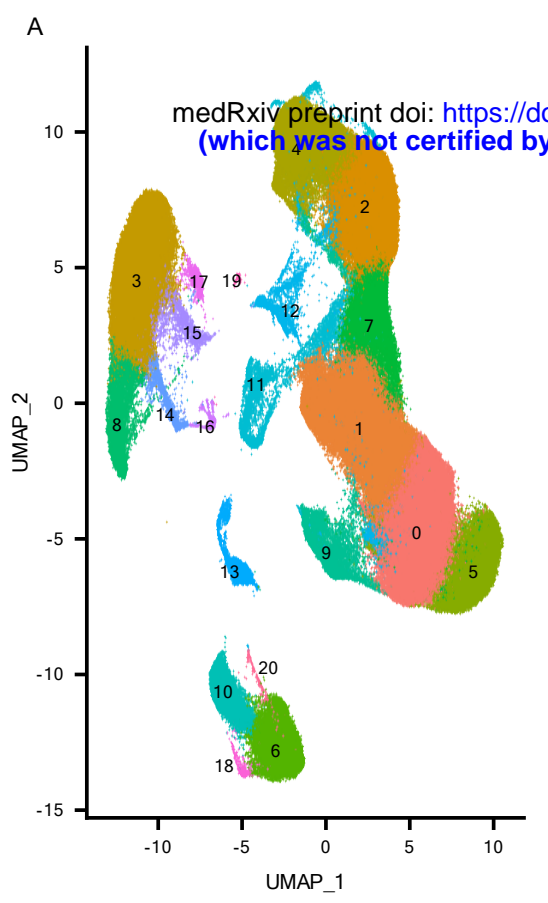

D

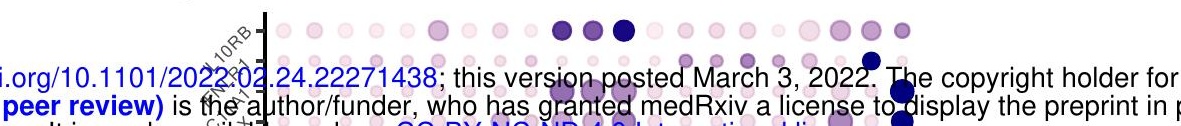
It is made axsiltablo e under a CC-BY-NC-ND 4. Onternational license.
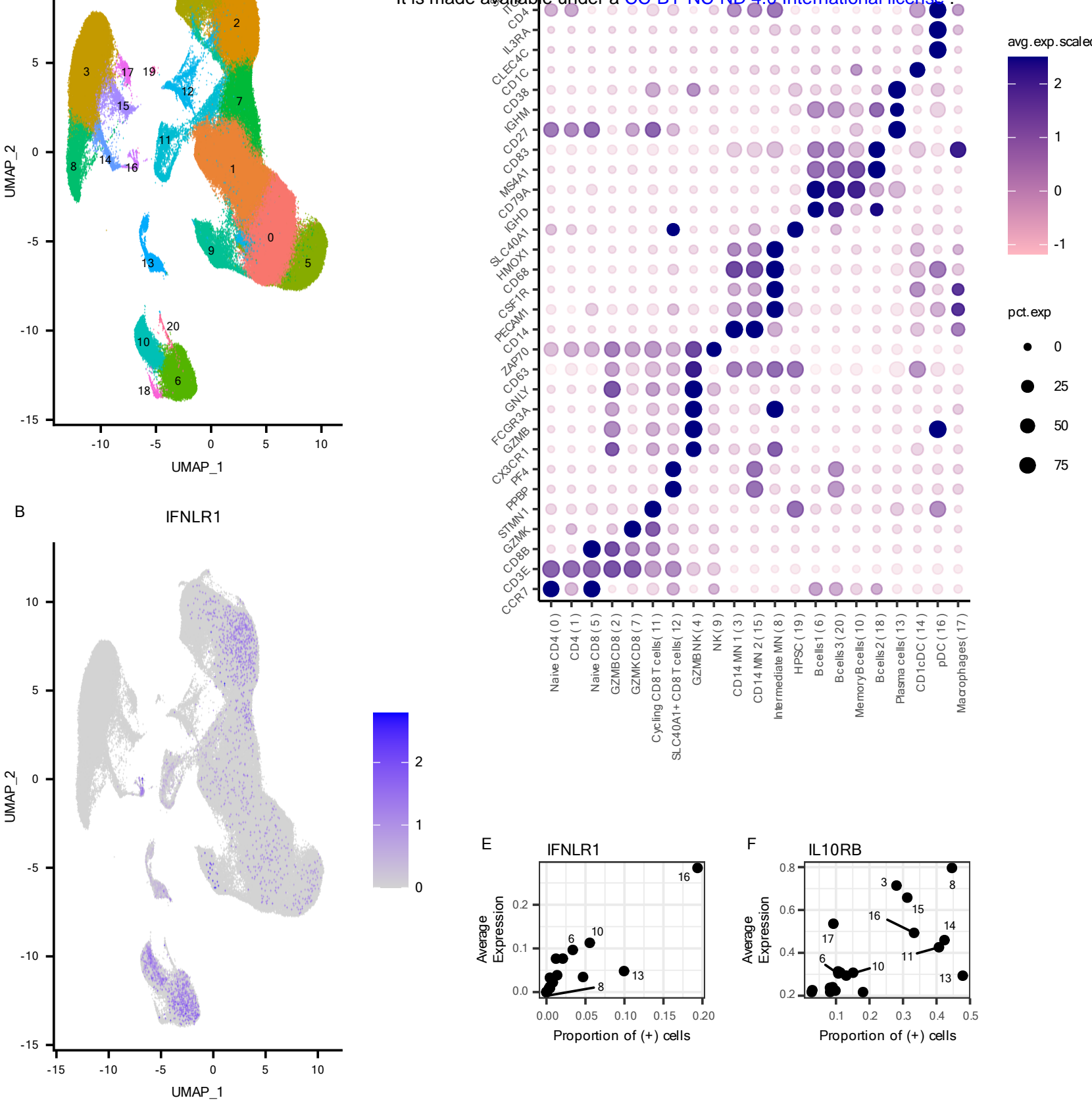

c
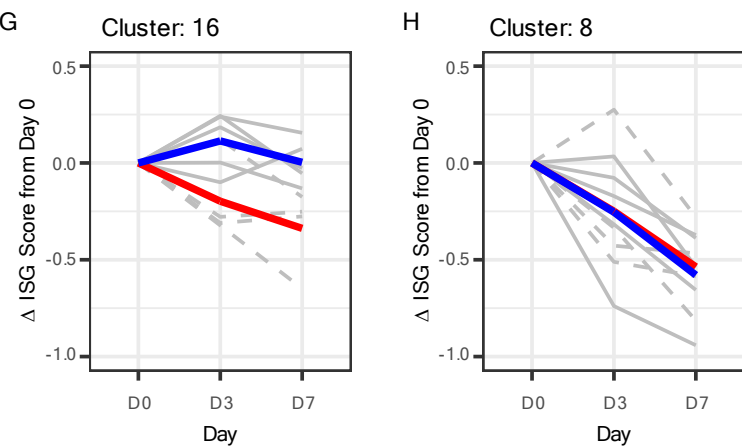

pct.exp
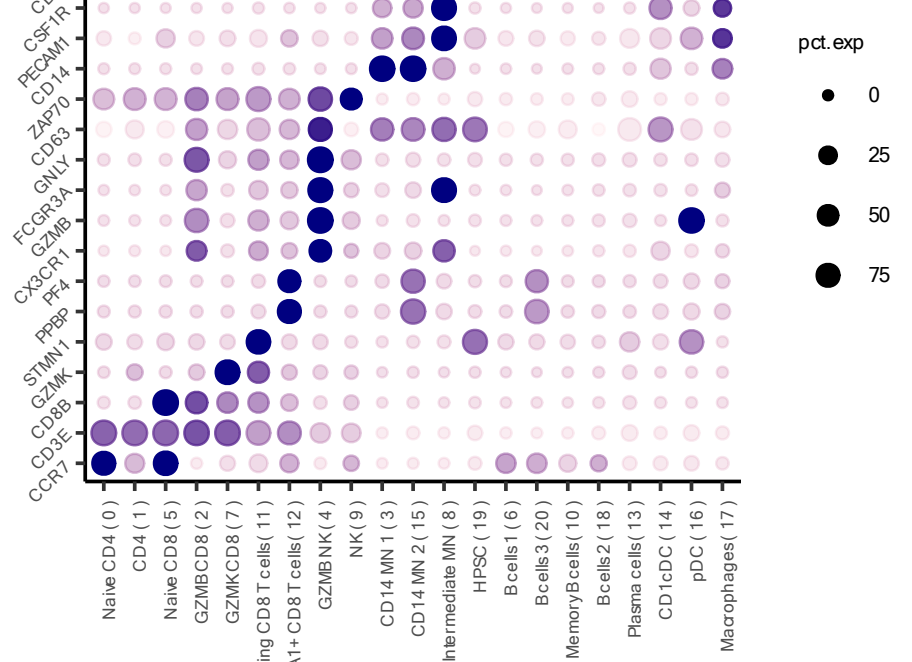
medRxiv preprint doi: https://doi.org/10.1101/2022.02.24.22271438; this version posted March 3, 2022. The copyright holder for this preprint (which was not certified by peer review) is the author/funder, who has granted medRxiv a license to display the preprint in perpetuity. It is made available under a CC-BY-NC-ND 4.0 International license.

Figure 1. Longitudinal scRNA-Seq analysis of cells from patients who were administered either PEG- $\lambda$ and placebo. A) UMAP projection and clustering identified 21 clusters. B) IFNLR1 and C) IL10RB expression in clusters are displayed on feature plots. D) Selected marker genes (x-axis) for each cluster ( $y$-axis) to confirm their annotation. Color and size of the points reflect the level and the proportion of expression, respectively, for each gene in each cluster. $y$-axis labels reflect the annotation and the number in the parentheses denote the cluster number. Proportion of cells which have non-zero E) IFNLR1 or F) IL10RB expression in each cluster. Y-axis denotes the average expression of the receptor in those cells in which it is expressed and $x$-axis denotes the proportion of these receptor-expressing cells in each cluster. $G$ ) Change in ISG score for cluster 16 (pDC) over time in patients treated with Peg-IFN- $\lambda$ or placebo. $H$ ) Change in ISG score for cluster 8 (monocytes) over time in patients treated with Peg-IFN- $\lambda$ or placebo. Y-axis denotes the change in ISG score compared to Day 0. Change in ISG score for I) cluster 6 and J) cluster $10 \mathrm{~B}$ cells when enriched for only cells that have non-zero IFNLR1 expression. Blue line is the average ISG score for 5 Peg-IFN- $\lambda$ treated patients, shown individually in solid grey lines. Red line is the average ISG score for 4 placebo treated patients, shown individually in dotted grey lines. 
medRxiv preprint doi: https://doi.org/10.1101/2022.02.24.22271438; this version posted March 3, 2022. The copyright holder for this preprint (which was not certified by peer review) is the author/funder, who has granted medRxiv a license to display the preprint in perpetuity.

It is made available under a CC-BY-NC-ND 4.0 International license .

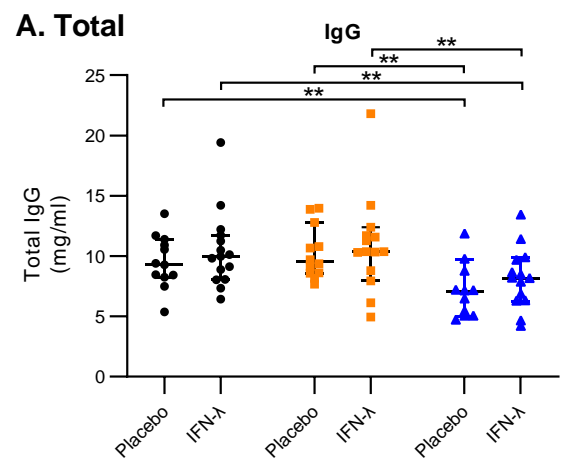

B. RBD

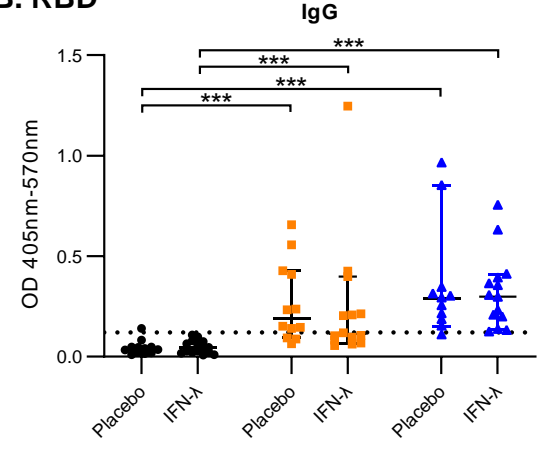

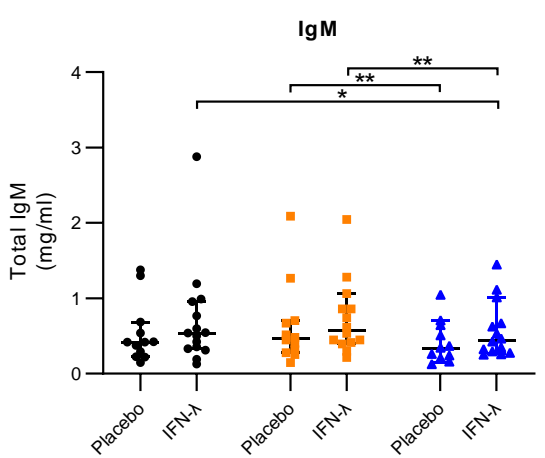

$\lg M$

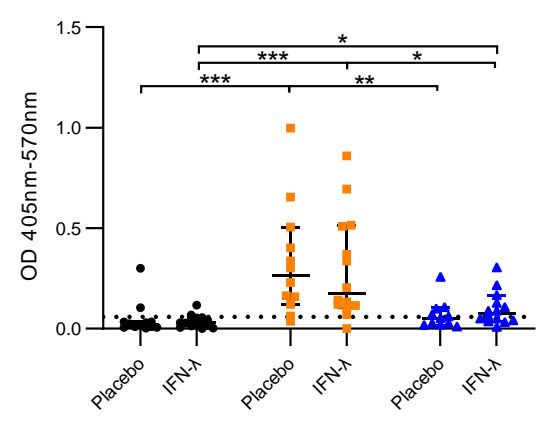

$\lg A$

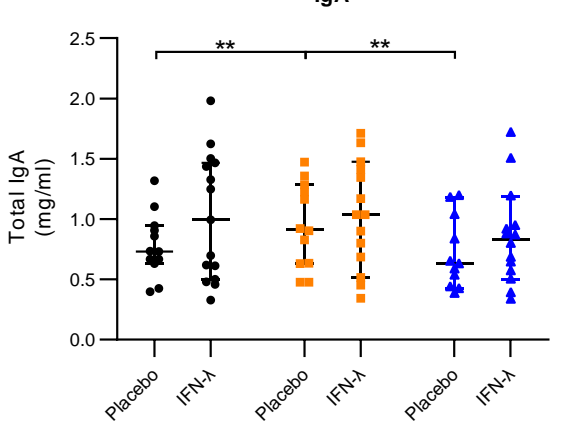

$\lg A$

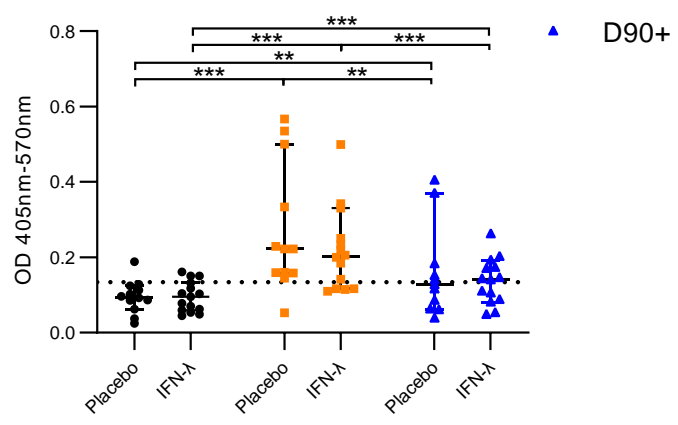

Figure 2. Comparison of total and SARS-CoV-2 spike-RBD plasma antibody levels between placebo and PEG-IFN- $\lambda$ treated patients at day $\mathbf{0}$, day $\mathbf{7}$, and day $\mathbf{9 0 +}$ post-enrollment. Total $\lg$, IgM and IgA and RBD-specific IgG, IgM and IgA in patient plasma were measured by ELISA from samples collected day 0 (D0), day 7 (D7) and day 90+ (D90+) post enrollment in the phase II clinical trial. Dashed line in B) represents the mean +2 SD of results obtained from 8 prepandemic plasma controls collected in 2018-2019. Each dot represents a different patient. Only significant differences between time points are shown where ${ }^{*}=p<0.05,{ }^{* *}=p<0.01,{ }^{* *}=p<0.001$ (Wilcoxon signed-rank test). Bar lines represent median and $95 \% \mathrm{Cl}$. 
medRxiv preprint doi: https://doi.org/10.1101/2022.02.24.22271438; this version posted March 3, 2022. The copyright holder for this preprint (which was not certified by peer review) is the author/funder, who has granted medRxiv a license to display the preprint in perpetuity.

It is made available under a CC-BY-NC-ND 4.0 International license.

A. IFN-Y

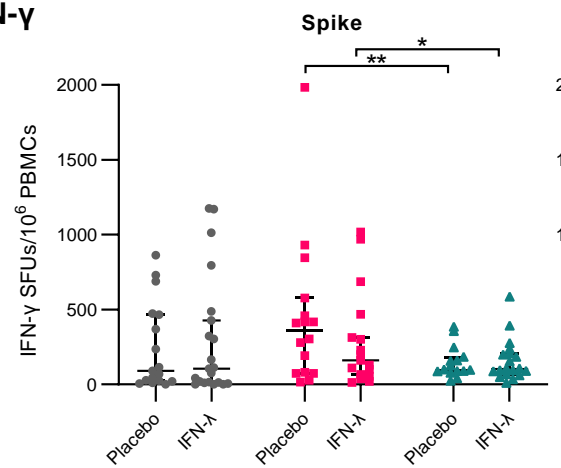

B. IL-2

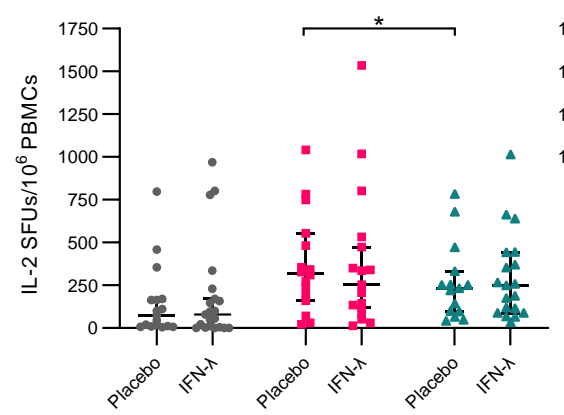

C. IFN-Y + IL-2

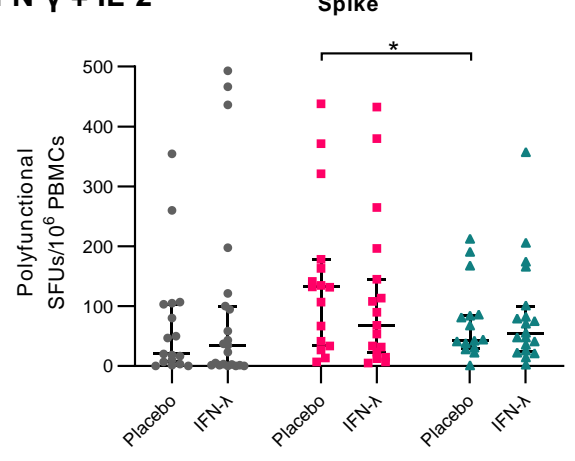

Nucleocapsid

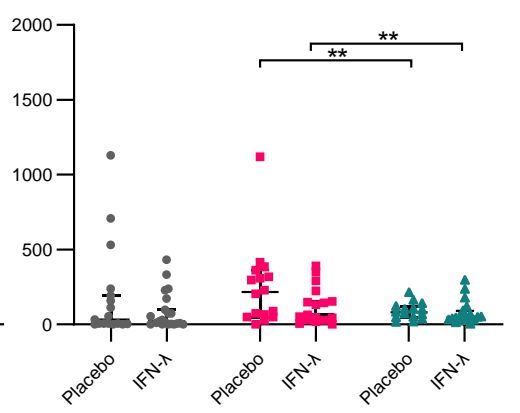

Nucleocapsid

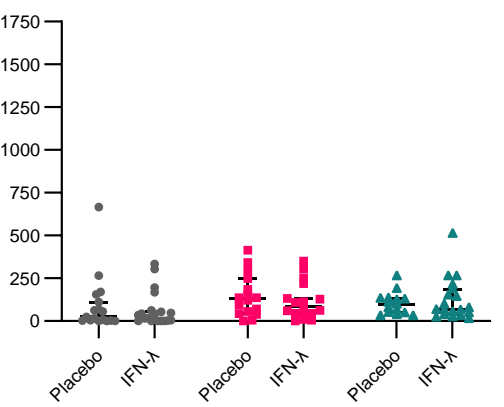

Nucleocapsid

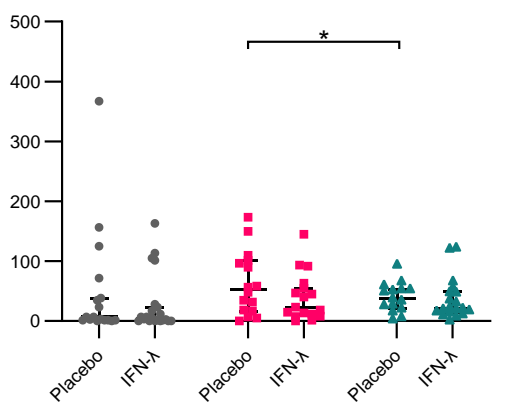

Membrane

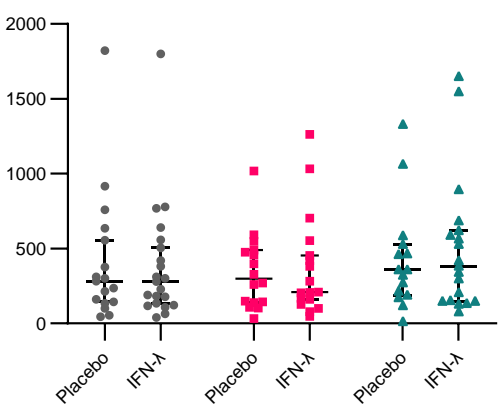

Membrane

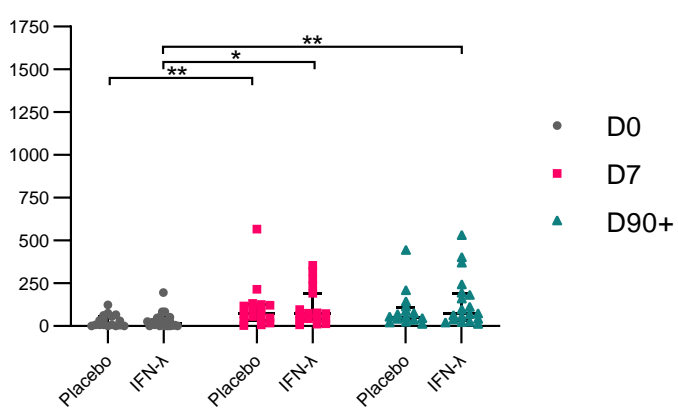

Membrane

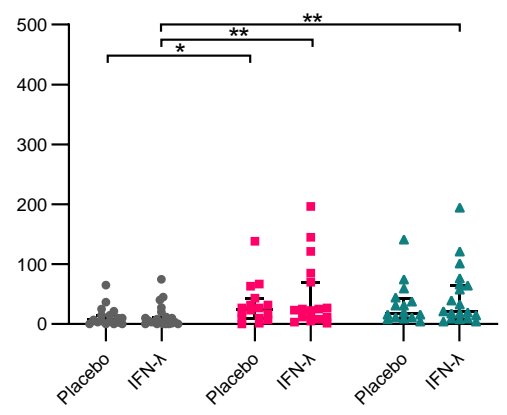

Figure 3. Comparison of T cell responses between placebo and PEG-IFN- $\lambda$ treated COVID-19 patients at day 0 , day 7, and day 90+ post enrollment. A) IFN- $\gamma$ B) IL-2 C) Polyfunctional (IFN- $\gamma+$ IL-2) T cell responses (as SFUs per $10^{6}$ PBMCs) against structural SARS-CoV-2 protein peptide pools were quantified ex vivo using fluorospot technology. Each dot represents a different patient. Only significant differences between time points are shown where $*=p<0.05, * *=p<$ $0.01, * * *=p<0.001$ (Wilcoxon signed-rank test). Bar lines represent median and $95 \% \mathrm{Cl}$. 
medRxiv preprint doi: https://doi.org/10.1101/2022.02.24.22271438; this version posted March 3, 2022. The copyright holder for this preprint (which was not certified by peer review) is the author/funder, who has granted medRxiv a license to display the preprint in perpetuity.

It is made available under a CC-BY-NC-ND 4.0 International license .

A. IFN-y

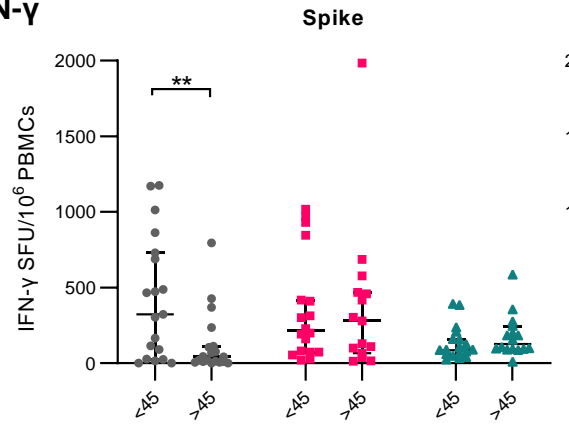

B. IL-2

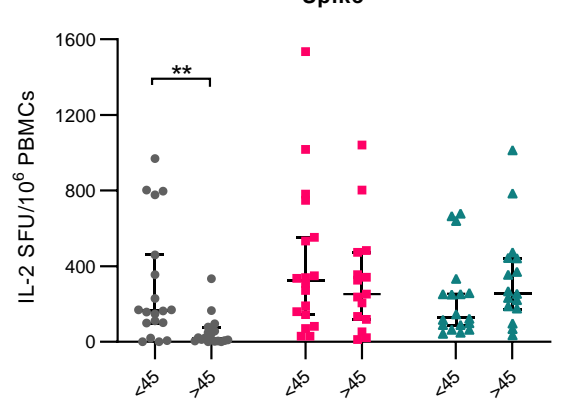

C. IFN-Y + IL-2

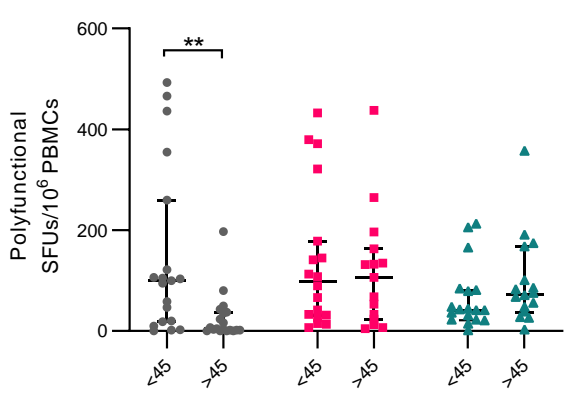

Nucleocapsid

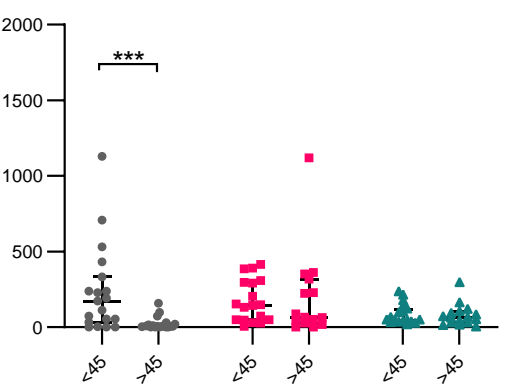

Nucleocapsid

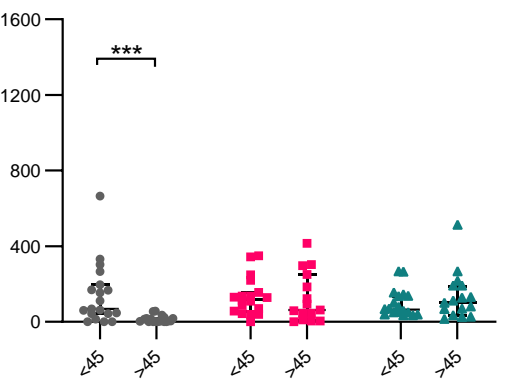

Nucleocapsid

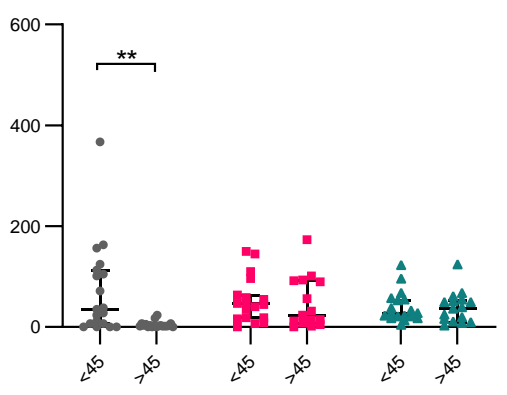

Membrane

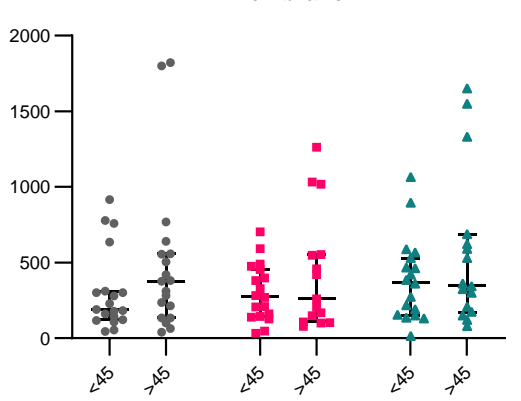

Membrane

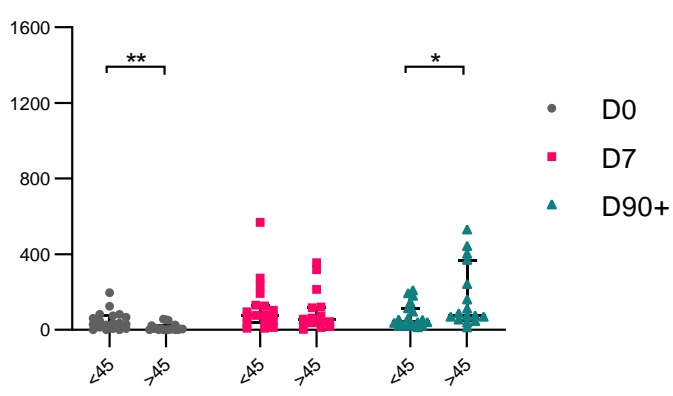

Membrane

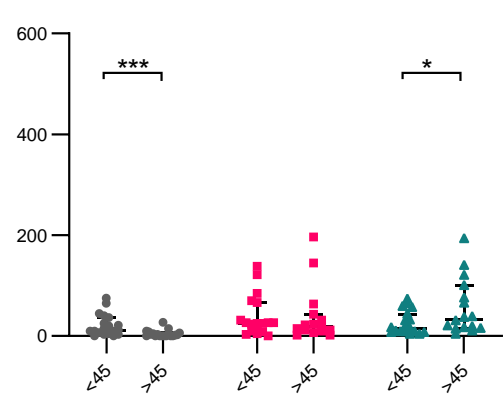

Figure 4. Differences in $\mathrm{T}$ cell responses between patients below and above the median age at day 0 , day 7, and day 90+ post-enrollment. A) IFN- $\gamma$ B) IL-2 C) Polyfunctional (IFN- $\gamma+$ IL-2) T cell responses (as SFUs per $10^{6}$ PBMCs) against structural SARS-CoV-2 protein peptide pools were compared between patients above and below the median age of the whole cohort (45 years old). Each dot represents a different patient. Only significant differences between groups are shown where ${ }^{*}=p<0.05,{ }^{* *}=p<0.01,{ }^{* *}=p<0.001$ (Mann-Whitney U-tests). Bar lines represent median and $95 \% \mathrm{Cl}$. 
medRxiv preprint doi: https://doi.org/10.1101/2022.02.24.22271438; this version posted March 3, 2022. The copyright holder for this preprint (which was not certified by peer review) is the author/funder, who has granted medRxiv a license to display the preprint in perpetuity.

It is made available under a CC-BY-NC-ND 4.0 International license .
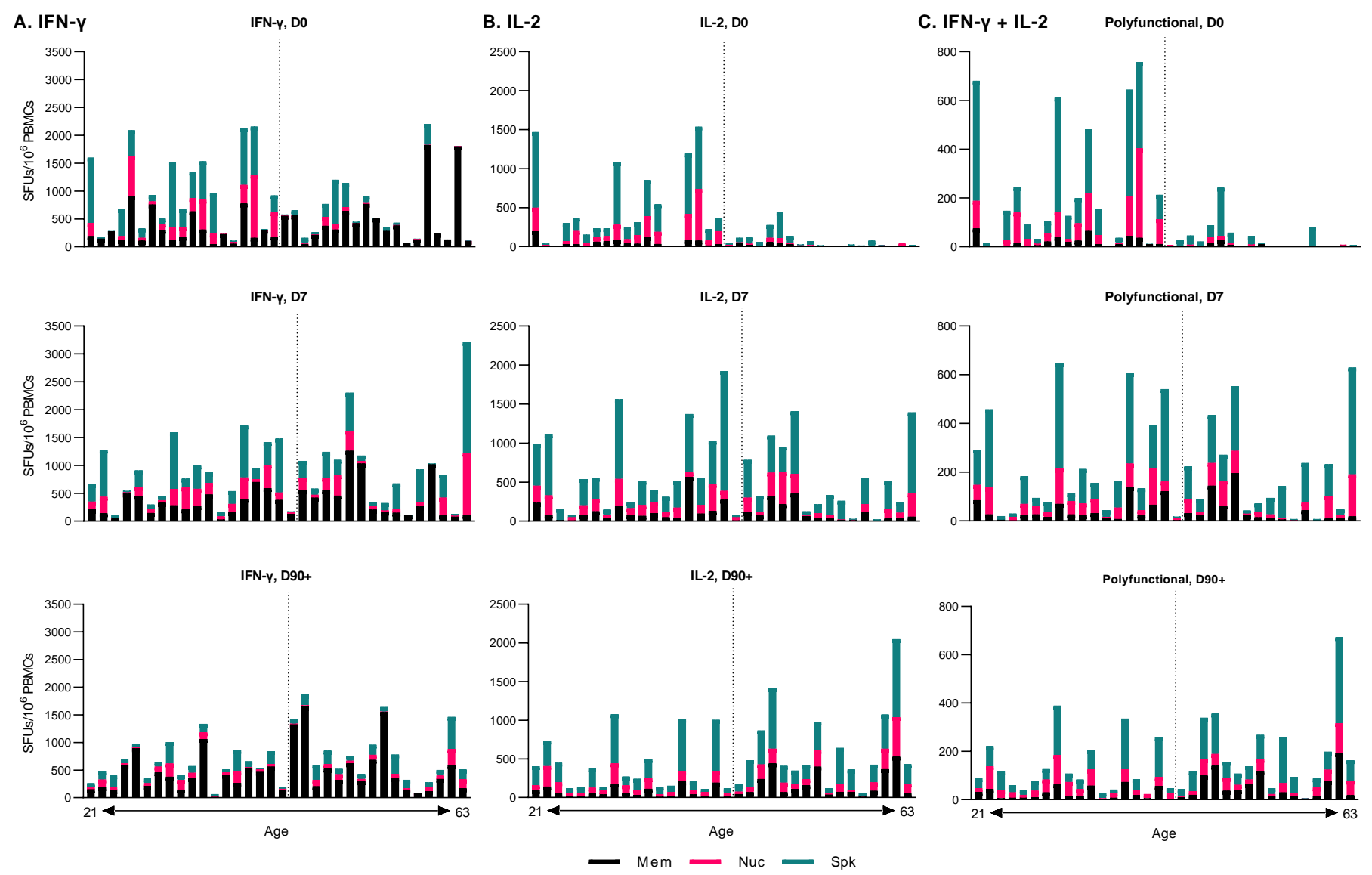

Figure 5. $T$ cell responses at day 0 , day 7 , and day $90+$ in increasing order of age. A) IFN- $\gamma$ B) IL-2 C) Polyfunctional (IFN- $\gamma$ + IL-2) T cell responses (as SFUs per $10^{6}$ PBMCs) against structural SARS-CoV-2 protein peptide. The dashed line represents the median age (45). Mem $=$ membrane, Nuc= nucleocapsid, Spk $=$ spike. 